\title{
PRAKTIK JASA PENITIPAN MOBIL DI RUSUNAWA TANAH MERAH UTARA SURABAYA MENGGUNAKAN TEORI SADD AL-DHARIAH
}

\author{
M. Faizal Fikih \\ Surabaya \\ fiqiwes7@gmail.com
}

\begin{abstract}
The practice of car care services in Rusunawa Tanah Merah Utara Surabaya is a service practice that uses an ijarah contract in accordance with the pillars and conditions of ijarah in Islamic law. However, the practice of custodial services has paved the way for fraudulent service actors, fraud in the results of service payments obtained every month. Due to the initial agreement between the person in charge of the care service and the manager and all residents of the flat, $60 \%$ of the income from the service goes to the flat cash and $40 \%$ is for the person in charge of the care service. However, the fact is that the results obtained by the person in charge of the care services are greater than the cash yields of the flats, this is not in accordance with the initial agreement. Then there is the negligence of the person in charge of the care service which results in losses for the car owner. In Sadd al-Dhari'ah theory, this kind of ijarah is not allowed and must be prevented. So that, the person in charge of the care service should pay attention to the agreement that has been agreed, be responsible for his duties with trust. For managers and other internal residents of the Flats, they should participate in monitoring the performance of the care services. Car owners should give a warning to the caretaker so that they are professionally responsible.
\end{abstract}

Keywords: Car Deposit, Ijarah, Saad Dhari'ah

Abstrak: penelitian praktik jasa penitipan mobil di Rusunawa Tanah Merah Utara Surabaya adalah praktik jasa yang menggunakan akad ijarah sesuai dengan rukun serta syarat ijarah yang ditetapkan dalam hukum Islam. Namun, praktik jasa penitipan telah membukakan jalan bagi pelaku jasa yang curang, kecurangan dalam $\mathrm{l}$ hasil dari pembayaran jasa yang diperoleh dalam setiap bulan. Karena kesepakatan awal antara penanggung jawab jasa penitipan dengan pengelola serta seluruh warga rusun mendapatkan hasil dari jasa tersebut sebanyak $60 \%$ untuk masuk kas rusun dan $40 \%$ untuk penanggung jawab jasa penitipan. Namun faktanya hasil yang diperoleh penanggung jawab jasa penitipan lebih besar dari hasil kas rusun, hal ini tidak sesuai dengan kesepakatan awal. Kemudian adanya kelalaian penanggung jawab jasa penitipan yang mengakibatkan kerugian bagi pemilik mobil. Dalam teori Sadd al-Dhari'ah, ijarah seperti ini tidak diperbolehkan dan harus dicegah. Maka bagi penanggung jawab jasa penitipan hendaknya memperhatikan kesepakatan yang telah disepakati, bertanggung jawab dengan tugasnyadengan amanah. Bagi pengelola dan warga internal Rusun yang lainnya hendaknya turut serta memantau kinerja dari jasa penitipan. Bagi pemilik mobil hendaknya memberikan teguran pada jasa penitipan tersebut supaya bertanggung jawab secara profesional.

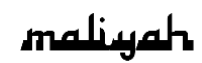

Jurnal Hukum Bisnis Islam

Volume 10, Nomor 02, Desember 2020

p-ISSN: 2088-4869/ e-ISSN: 2597-4351 
Kata Kunci: Penitipan Mobil, Ijarah, Saad Dhariah

\section{Pendahuluan}

Sebagai makhluk hidup, manusia berusaha memenuhi kebutuhannya sendiri agar dapat bertahan hidup. Sebagai pencipta umat manusia, Allah telah memenuhi kebutuhan mereka untuk diseminasi secara luas di muka bumi. Bahkan Allah telah memberkati dunia dan segalanya bagi umat manusia. Segala sesuatu di bumi terbagi menjai dua bagian: baik dan buruk, Allah telah membuktikan baik, jahat dan melarang hal-hal buruk, oleh karena itu Allah mewajibkan manusia menerima hal-hal yang baik dan melepaskan hal-hal buruk. Allah telah berfirman:

"Dialah (Allah) yang menciptakan segala apa yang ada di bumi untukmu...." (Q.S. Al-Baqarah 2:29). ${ }^{1}$

Islam merupakan agama yang sempurna dalam mengatur semua aspek kehidupan. Salah satunya adalah aturan atau hukum mengenai hubungan antara sesama manusia. Islam memerintahkan manusia untuk bekerja sama dalam segala hal, kecuali dalam hal berbuat dosa kepada Allah dan melakukan penganiayaan kepada sesama makhluk. ${ }^{2}$ Sebagaimana firman Allah SWT dalam surat an-Nisa' ayat 29 yang artinya: "Wahai orang-orang yang beriman, janganlah kamu saling memakan harta sesamamu dengan jalan yang bathil, kecuali dalam perdagangan yang berlaku atas dasar suka sama suka di antara kamu. Dan janganlah kamu membunuh dirimu.Sungguh, Allah Maha Penyayang kepadamu."(Q.S. an-Nisa' 4:29). ${ }^{3}$

Dalam kehidupan sehari-hari, manusia tetap berhubungan dengan manusia lain. Mu'amalah merupakan bagian dari hokum Islam, yang mengatur hubungan antara dua

\footnotetext{
${ }^{1}$ Kemenag RI, Al-Qur'an Kemenag (Jakarta: Lajnah Pentashihan Mushaf AlQur'an, 2018).5

${ }^{2}$ Ismail Nawawi, Ekonomi Islam- Teori, Sistem, Dan Aspek Hukum (Surabaya: CV. Putra Media Nusantara, 2009).51

${ }^{3} \mathrm{RI}$, Al-Qur'an Kemenag. 83
} 
atau lebih dan antara individu dengan individu lain. Maupun badan hukum seperti perseroan, firma, yayasan, Negara, dan sebagainya. Muamalah merupakankata dari bahasa Arab yang memiliki makna saling berbuat. Kata ini menggambarkan suatu aktifitas yang dilakukan oleh seseorang dengan seseorang atau beberapa orang dalam memenuhi kebutuhan masing-masing. ${ }^{4}$

Dalam kehidupan sehari-hari manusia hidup saling berhubungan dalam hal bermu'amalah dengan sesama. Mu'amalah merupakan bagian dari hukum Islam yang mengatur hubungan antara dua pihak atau lebih, baik antara pribadi dengan pribadi lain, maupun antar badan hukum seperti perseroan, firma, yayasan, Negara, dan sebagainya. Muamalah merupakankata dari bahasa Arab yang memiliki makna saling berbuat. Kata ini menggambarkan suatu aktifitas yang dilakukan oleh seseorang dengan seseorang atau beberapa orang dalam memenuhi kebutuhan masing-masing. ${ }^{5}$

Awalnya cakupan muamalah di dalam fikih meliputi permasalahan keluarga, seperti perkawinan dan perceraian. Namun, setelah terjadi disintegrasi di dunia Islam, khususnya di zaman Utsmani (Turki Ottoman), terjadi perkembangan pembagian fikih, sehingga cakupan bidang mu'amalah dipersempit, sehingga masalah yang berhubungan dengan hukum keluarga tidak masuk lagi dalam pengertian muamalah. Kemudian mu'amalah dipahami sebagai hukum yang berkaitan dengan perbuatan manusia dengan sesamanya yang menyangkut harta dan hak serta penyelesaian kasus diantara mereka. Dari pengertian tersebut dapat dipahami bahwa mu'amalah hanya mengatur permasalahan harta dan hak yang muncul dari transaksi antara seseorang dengan seseorang yang lain, atau antara seseorang dengan badan hukum, atau antara badan hukum dengan badan hukum yang lain. ${ }^{6}$

\footnotetext{
${ }^{4}$ Nasrun Harun, Fiqh Muamalah (Jakarta: Gaya Media Pratama, 2000).7

${ }^{5}$ Ibid. 7

${ }^{6}$ Nurfaizal, "Prinsip-Prinsip Muamalah Dan Implementasinya Dalam Hukum

Perbankan Indonesia," Jurnal Hukum Islam Vol.13 (2013): 193.
} 
Pada dasarnya dalam bermu'amalah terdapat beberapa prinsip yang harus di pegang teguh oleh para pelaku mu'amalah, diantaranya yaitu: ${ }^{7}$

1. Pada dasarnya segala bentuk mu'amalah hukumnya adalah mubah, sampai ada dalil yang mengharamkannya. Artinya hukum Islam memberi kesempatan luas atas berkembangnya berbagai macam bentuk dan macam dari kegiatan bermu'amalah sesuai dengan perkembangan kebutuhan hidup masyarakat.

2. Kegiatan bermu'amalah dilakukan atas dasar sukarela, artinya tidak ada unsur paksaan dalam kegiatan bermu'amalah, agar kebebasan kehendak dari pihak-pihak yg bersangkutan selalu diperhatikan.

3. Kegiatan bermu'amalah dilakukan atas dasarpertimbangan apakah kegiatan tersebut mendatangkan manfaat atau justru mendatangkan mudharat. Maka dalam hukum Islam sangat mengharuskan untuk melakukan kegiatan bermu'amalah yang mendatangkan kemanfaatan dan menghindari kemudharatan dalam kehidupan bermasyarakat.

4. Mu'amalah dilaksanakan dengan memelihara nilai keadilan, menghindari unsur-unsur penganiayaan, unsurunsur pengambilan kesempatan dalam kesempitan. Bahwa segala bentuk muamalat yang mengundang unsur penindasan tidak dibenarkan.

Di tengah perkembangan zaman yang sangat pesat saat ini, banyak pelaku mu'amalah yg tidak memegang teguh prinsip-prinsip dasar dalam kegiatan bermu'amalah. Banyak para pelaku muamalah yang melakukan kegiatan mu'amalah dengan hanya mementingkan keuntungannya sendiri tanpa memandang apakah kegiatan tersebut menimbulkan maslahah atau bahkan menimbulkan mudharat bagi orang-orang di sekitarnya.

7 "Pengertian Fiqih Muamalah," accessed March 30, 2018, http://artikelilmiahlengkap.blogspot.com/.Akses Tgl 30 Maret 2018 
Praktik jasa penitipan mobil di Rusunawa Tanah Merah Utara Surabaya adalah suatu kegiatan penyediaan jasa oleh security Rusun, bagi warga luar rusun yang memiliki mobil agar dititipkan di halaman Rusun dengan membayar biaya per bulan. Penyediaan jasa dalam istilah fikih mu'amalah disebut dengan istilah ijarah. Ijarah merupakan kegiatan mu'amalah yang dilakukan untuk memenuhi kebutuhan hidup manusia, sewa menyewa kontrak dan menjual jasa kepada pihak yang membutuhkan dengan saling suka rela. ${ }^{8}$ Ijarah adalah menggunakan manfaat dari suatu barang yang jelas diketahui dan diperbolehkan menurut syara' kemudian menggantinya dengan imbalan yang telah disepakati bersama. ${ }^{9}$ Sebagaimana firman Allah dalam Q.S. Al-Baqarah ayat 233 yang berbunyi:

“......Dan jika kamu ingin menyusukan anakmu pada orang lain, maka tidak ada dosa bagimu memberikan pembayaran dengancara yang patut. Bertakwalah kepada Allah dan ketahuilah bahwa Allah maha melihat apa yang kamu kerjakan."(Q.S. al-Baqarah 2: 233). ${ }^{10}$

Kemudian hadis Rasulullah SAW yang diriwayatkan oleh Ibnu Majah, Rasulullah bersabda:

"Dari Abu Hurairah sesungguhnya Rasulullah bersabda: "Berikanlah upah kepada orang yang bekerja sebelum keringatnya kering". (HR. Ibnu Majah). ${ }^{11}$

Pada dasarnya sumber hukum dalam Islam hanya bersumber pada Al-Qur'an dan Hadis. Namun seiring dengan perkembangan Islam yang sangat pesat, maka muncullah berbagai macam metode dalam penggalian hukum Islam yang dimunculkan oleh para mujtahid, sehingga muncul sumber hukum yang disepakati oleh para ulama' dan sumber hukum yang diperselisihkan oleh para ulama'. Hukum yang disepakati

\footnotetext{
${ }^{8}$ Boedi Abdullah and Ahmad Saebani, Metode Penelitian Ekonomi Islam

(Bandung: Pustaka Setia, 2014). 119

${ }^{9}$ Wahbah Zuhaili, Fiqih Islam Wa Adillatuhu, 2011.3803

${ }^{10}$ RI, Al-Qur'an Kemenag.37

${ }^{11}$ Muhammad Yazid, Hukum Ekonomi Islam (Fiqih Muamalah) (Surabaya: UIN Sunan Ampel Press, 2014).197
} 
oleh jumhur ulama' adalah hukum pokok dalam Islam yang bersumber pada Al-Qur'an dan Hadis. Sedangkan hukum yang diperselisihkan oleh jumhur ulama' adalah hukum yang diperoleh dari ijtihad para ulama', sehingga untuk melakukan istinbath hukum menggunakan metode Istihsan, Istishab, alMashlahah al-Mursalah, al-Istihsan, al-Istishab, al-'urf, Sadd aldhari'ah dan lainnya.

Namun dalam penelitian ini penulis fokus menggunakan satu metode, yaitu metode sadd-dhari'ah. Sadd al-dhari'ah terdiri dari dua kata, yaitu sadd dan al-dhari'ah. Sadd artinya menutup, sedangkan Al-dhari'ah adalah segala sesuatu yang awalnya boleh dilakukan namun bisa mengantarkan dan menjadi jalan menuju sesuatu yang dilarang oleh syara' karena menimbulkan kemafsadatan. ${ }^{12}$ Oleh karena itu segala hal yang mengantarkan pada sesuatu yang dilarang oleh syara' dan menimbulkan kemafsadatan harus ditutup (sadd), dicegah atau dihindari.

Adanya praktik jasa penitipan mobil di Rusunawa Tanah Merah Surabaya berawal dari salah satu warga internal rusun yang berprofesi sebagai sopir dari suatu perusahaan, kemudian mobil perusahaan tempat dia bekerja itu dibawa pulang dan diparkirkan di halaman Rusunawa Tanah Merah Surabaya. Kemudian salah satu warga eksternal Rusun yang berminat untuk menitipkan mobilnya di halaman Rusun tersebut mengutarakan ketertarikannya tersebut dengancara langsung menemui warga internal Rusun yang memarkirkan mobil di halaman Rusun. Sampai akhirnya terjadilah kesepakatan anatara beberapa warga internal Rusun, pengelola rusun dan warga eksternal Rusun yang hendak menitipkan mobil di halaman Rusun dengan ujrah sebesar Rp. 300.000 per bulan yang harus dibayar oleh masing-masing pemilik mobil.

Praktik jasa penitipan mobil di Rusunawa Tanah Merah Utara Surabaya tersebut terkesan membuka jalan untuk melakukan sesuatu yang dilarang. Karena pada kenyataannya

12 Zuhaili, Fiqih Islam Wa Adillatuhu.873 
ada kecurangan yang dilakukan oleh penanggung jawab jasa penitipan mobil terkait ujrah dari praktik jasa penitipan mobil tersebut. Pada kesepakatan awal terkait pembagian hasil antara penanggung jawab jasa penitipan mobil dengan seluruh warga rusun dan pengelola rusun yaitu sebesar $60 \%$ masuk ke kas rusun dan $40 \%$ untuk penanggung jawab jasa penitipan mobil. Namun kenyataannya hasil yang dinikmati oleh penanggung jawab jasa penitipan mobil lebih besar daripada hasil yang masuk ke kas rusun. Maka disana ada kecurangan dalam praktik jasa penitipan mobil di Rusunawa Tanah Merah Utara Surabaya.

Maka berdasarkan permasalahan praktik jasa penitipan mobil di Rusunawa Tanah Merah Utara Surabaya yang telah dijelaskan diatas, penulis ingin melakukan penelitian lebih lanjut langsung di Rusunawa Tanah Merah Utara Surabaya. Dari uraian diatas, penulis ingin menganalisis praktik jasa penitipan mobil berdasarkan nilai mashlahah dan mafsadah yang ditimbulkan dari kegiatan tersebut, sehingga praktik jasa penitipan mobil di Rusunawa Tanah Merah Utara Surabaya mempunyai kepastian hukum ditinjau menurut analisis sadd aldhari'ah. Oleh karena itu, penulis ingin mengkaji lebih lanjut dalam sebuah skripsi yang berjudul "Analisis Sadd Al-dhari'ah terhadap praktik jasa penitipan mobil di Rusunawa Tanah Merah Utara Surabaya".

Penelitian tentang "Sadd al-Dhari 'ah Terhadap Praktik Jasa Penitipan Mobil di Rusunawa Tanah Merah Utara Surabaya" Merupakan penelitian dengan penggalian data langsung di lapangan (field research) yakni kegiatan penelitian yang dilakukan dalam keseharian sebenarnya dan litelature research (kepustakaan) yaitu teknik pengumpulan data dengan mengadakan studi penelaahan terhadap buku-buku, literature, catatan dan laporan yang ada hubungannya dengan masalah yang dipecahkan. Obyek dalam penelitian ini yaitu Rusunawa Tanah Merah Utara Surabaya beserta para pihak yang melakukan praktik jasa penitipan mobil.

\section{Sadd al-Dhari'ah dan Ijarah Dalam Islam}


Menurut istilah ahli hukum Islam, al-Dhari'ah adalah sesuatu yang menjadi perantara kearah perbuatan yang diharamkan atau dihalalkan. Dari segi bahasa kata Sadd alDhari'ah terdiri dari dua kata, yaitu Sadd yang artinya menutup dan kata al-Dhari'ah yang berarti jalan.Jadi secara bahasa Sadd al-Dhari'ah artinya menutup jalan. ${ }^{13}$

Akan tetapi Ibnu Qayyim al-Jauziyah mengatakan bahwa al-Dhari'ah tidak hanya terbatas kepada sesuatu yang dilarang, melainkan ada juga al-Dhari'ah yang bertujuan kepada sesuatu yang dianjurkan. ${ }^{14}$ Oleh sebab itu menurutnya al-Dhari'ah mengandung dua pengertian, yaitu sesuatu yang dilarang (Sadd al-Dhari'ah) dan sesuatu yang dituntut untuk dilaksanakan (Fath al-Dhari'ah).

Sedangkan menurut istilah syara' Sadd al-Dhari'ah adalah segala sesuatu yang awalnya boleh dilakukan namun bisa mengantarkan dan menjadi jalan menuju sesuatu yang dilarang oleh syara' karena menimbulkan kemafsadatan. ${ }^{15}$ Menurut Abdullah bin Yusuf bin 'Isa bin Ya'qub al-Ya'qub al'Unzi al-Dhari'ah adalah jalan yang membawa kepada sesuatu yang dilarang yang mengandung mafsadah (kerusakan), atau yang membawa kepada sesuatu yang dianjurkan yang mengandung mashlahah. ${ }^{16}$ Menurut al-Syatibi menyatakan bahwa Sadd al-Dhari'ah adalah menolak sesuatu yang boleh agar tidak mengantarkan kepada sesuatu yang dilarang. ${ }^{17}$ Menurut Yahya dan Fatchurrahman Sadd al-Dhari'ah adalah menutup jalan yang menuju pada perbuatan yang dilarang. ${ }^{18}$

\footnotetext{
${ }^{13}$ Sapiudin Shidiq, Ushul Fiqh, Cet.1. (Jakarta: Prenada Media Group, 2011).104

${ }^{14}$ Ibn al-Qayyim Al-Jauzaiyah, A 'lam Al-Muwaqi'in, Jilid 3 (Beirut: Dar alKutub al-'Ilmiyah, 1996).147

${ }^{15}$ Zuhaili, Fiqih Islam Wa Adillatuhu.873

${ }^{16}$ Abdullah bin Yusuf bin 'Isa bin Ya'qub al-Ya'qub al-Jadi' Al-Unzi, Taysir 'Ilmi Ushul Al-Fiqh (Beirut: Muassasah al-Rayyan li al-Thaba'ah, 1997).203

${ }^{17}$ Ibrahim bin Musa al-Lakhmi al-Gharnathi al-Maliki Al-Syatibi, , Al-

Muwafaqat Fi Ushul Al-Fiqh Juz 3 (Beirut: Dar al-Ma'rifah, n.d.).

${ }^{18}$ Mukhtar Yahya and Fatchurrahman, Dasar-Dasar Pembinaan Hukum Islam (Bandung: PT. Al-Ma'arif, 1986).347
} 
Dari beberapa definisi di atas dapat diperoleh gambaran secara jelas bahwa Sadd al-Dhari'ah merupakan usaha mujtahid untuk menetapkan larangan terhadap satu kasus hukum yang dasar hukumnya mubah tetapi akan membawa kepada perbuatan yang haram, maka hukumnya menjadi haram. Metode ini merupakan usaha preventif atau pencegahan terhadap sesuatu yang pada dasar hukumnya mubah tetapi akan membawa kepada perbuatan yang yang haram karena menimbulkan kemafsadatan. ${ }^{19}$

Ada beberapa nash yang mengarah pada pembahasan Sadd al-Dhari'ah, baik dalam al-Qur'an maupun hadis, dan juga kaidah fikih, yaitu:

Al-Baqarah 2: 104: "Wahai orang-orang yang beriman. Janganlah kamu katakan (kepada Muhammad) "raa'inaa", tetapi katakanlah "unzhurnaa" dan dengarkanlah. Maka dan orang-orang kafir akan mendapat azab yang pedih". (QS. Al-Baqarah 2: 104). ${ }^{20}$

Dalam ayat ini dinyatakan bahwa orang mu'min dilarang mengucapkan kata "raa'inaa" (suatu ucapan yang biasa digunakan orang Yahudi untuk mencela atau mengejek Nabi). Larangan ini didasarkan atas keyakinan bahwa pengucapan itu akan membawa pada mafsadah, yaitu mencela atau mengejek Nabi. 21

Al-An'am 6: 108: "Dan janganlah kamu memaki sesembahan yang mereka sembah selain Allah, karena mereka nanti akan memaki Allah dengan melampaui batas tanpa dasar pengetahuan". (QS. Al-An'am 6:108). ${ }^{22}$ Maksud dari penjelasan ayat di atas pada hakikatnya adalah memaki sesembahan kaum musyrikin itu boleh, namun akan berdampak fatal jika kaum musyrik membalas memaki Allah SWT beserta agamanya. Dengan demikian, sebelum balasan

\footnotetext{
${ }^{19}$ Shidiq, Ushul Fiqh.104

${ }^{20} \mathrm{RI}$, Al-Qur'an Kemenag. 16

${ }^{21}$ Asmawi, Perbandingan Ushul Fiqh (Jakarta: Sinar Grafika Offest, 2011).144

${ }^{22}$ RI, Al-Qur'an Kemenag.141
} 
cacian itu dilakukan, maka larangan mencaci maki tuhan agama lain merupakan tindakan preventif.

Hadis:"Dari Abdullah bin Umar RA, Rasulullah SAW bersabda: Sesungguhnya yang termasuk dosa besar adalah seorang lelaki yang melaknat kedua orang tuanya. Kemudian Rasul ditanya, bagaimana caranya seorang lelaki melaknat kedua orang tuanya Rasul menjawab: seorang lelaki yang mencaci maki ayah orang lain, kemudian orang yang dicaci itu membalas mencaci maki ayah dan ibu lelaki tersebut". ${ }^{23}$ Menurut Ibnu Taymiyyah, hadis tersebut menunjukkan bahwa Sadd al-Dhari'ah termasuk salah satu alasan untuk menetapkan hukum syari'at, karena sabda Rasulullah SAW di atas masih bersifat dugaan. Akan tetapi atas dasar dugaan ini Rasulullah SAW telah melarangnya. ${ }^{24}$

Kaidah Fikih "Menolak keburukan (mafsadah) lebih diutamakan daripada meraih kebaikan (mashlahah)". ${ }^{25}$

Penjelasan kaidah di atas adalah bahwa menolak atau mencegah segala perbuatan yang dilarang syri'at terkadang ada yang menyampaikan dengan sendirinya pada kerusakan tanpa perantara, seperti zina, pencurian, dan pembunuhan. Ada juga yang tidak menyampaikan dengan sendirinya, tetapi dia menjadi wasilah agar dapat menyampaikan pada kerusakan tersebut, seperti khalwat yang menjadi sebab terjadinya percampuran keturunan. Khalwat menjadi perantara pada zina yang menimbulkan kerusakan. ${ }^{26}$

Ijarah secara bahasa berasal dari kata al-ajru yang berarti al-'iwadhu (ganti). Maka ijarah adalah suatu transaksi sewa menyewa antara pihak penyewa dengan yang menyewakan sesuatu untuk diambil manfaatnya dengan harga

\footnotetext{
${ }^{23}$ Asmawi, Perbandingan Ushul Fiqh.144

${ }^{24}$ Nasrun Haroen, Ushul Fiqh 1 (Jakarta: Logos, 1996).164

${ }^{25}$ Ahmad Djazuli, Kaidah-Kaidah Fiqh (Jakarta: Kencana, 2006). 164

${ }^{26}$ Hasbi Ash-Shiddieqy, Falsafah Hukum Islam (Jakarta: PT. Bulan Bintang, 1993).322
} 
tertentu dan dengan jangka waktu tertentu. ${ }^{27}$ Dalam arti yang luas, ijarah bermakna suatu akad yang berisi penukaran manfaat dengan cara memberikan imbalan dalam jumlah yang di tentukan.

Secara terminologi, terdapat beberapa definisi ijarah yang dijelaskan oleh para ulama' fikih, yaitu:

Menurut Ulama' Syafi'iyah: “ijarah adalah suatu akad atas penggunaan suatu manfaat yang disengaja, diketahui, diperbolehkan dan bisa diberikan dengan ganti (upah) yang telah diketahui." 28 Menurut Ulama' Malikiyah dan Hanabilah: "ijarah adalah memiliki atau menggunakan manfaat dari sesuatu yang diperbolehkan dengan jangka waktu tertentu dengan memberikan ganti (upah)." 29 Menurut Ulama' Hanafiyah: "ijarah adalah transaksi terhadap suatu manfaat dengan imbalan." 30

Menurut Hasbi Ash Shiddiqie: "Akad yang objeknya menukarkan manfaat dari sesuatu untuk jangka waktu tertentu, yaitu pemilikan manfaat dengan imbalan, sama dengan menjual manfaat."31 Menurut Sayyid Sabiq: ijarah adalah jenis akad untuk mengambil manfaat dengan jalan penggantian. ${ }^{32}$ Menurut Imam Taqiyyudin: ijarah adalah perjanjian untuk mengambil suatu barang denagn tujuan yang diketahui dengan penggantian, dan dibolehkan sebab ada penggantian yang jelas.

Menurut Syeikh al-Imam Abi Yahya Zakariya al-Anshori dalam kitab Fath al-Wahhab: ijarah adalah memiliki atau mengambil manfaat suatu barang dengan imbalan dengan

\footnotetext{
${ }^{27}$ Saiful Jazil, Fiqih Mu'amalah (Surabaya: UIN Sunan Ampel Press, 2014).127

${ }^{28}$ Zuhaili, Fiqih Islam Wa Adillatuhu.2804

${ }^{29}$ Ibid.

${ }^{30}$ Muhammad Yazid, Hukum Ekonomi Islam (Fiqh Muamalah) (Sidoarjo: CV

Cahaya Intan XII, 2014). 195

${ }^{31}$ Harun, Fiqh Muamalah.85

32 Jazil, Fiqih Mu'amalah.127
} 
syarat-syarat yang sudah ditentukan. ${ }^{33}$ Menurut Syarifuddin: Ijarah secara bahasa dapat diartikan dengan akad transaksi manfaat atau jasa dengan imbalan tertentu. Bila yang menjadi objek transaksi adalah manfaat dari suatu benda disebut Ijarah al'ain. Sedangkan bila yang menjadi objek transaksi manfaat dari jasa tenaga seseorang disebut Ijarah al-dzimah atau upah mengupah. Meskipun ada perbedaan dalam hal objek, namun tetap dalam konteks fikih disebut dengan Ijarah. ${ }^{34}$

Dari beberapa pengertian di atas dapat ditarik kesimpulan bahwa ijarah adalah suatu jenis perikatan atau perjanjian yang bertujuan mengambil manfaat suatu benda yang diterima dari orang lain dengan jalan mengambil upah sesuai dengan perjanjian dan kerelaan kedua belah pihak dengan rukun dan syarat yang telah ditentukan. Dalam istilah hukum Islam pemilik yang menyewakan manfaat disebut mu'ajjir (orang yang menyewakan).Pihak yang menyewa manfaat disebut musta'jir (penyewa). Dan sesuatu yang diakadkan untuk diamnbil manfaatnya disebut ma'jur (sewaan). Sedangkan imbalan yang dierikan atas suatu manfaat disebut ajran atau ujrah. ${ }^{35}$

Jumhur Fukaha' menyimpulkan kebolehan akadija@rah dengan berlandaskan pada al-Qur'an, hadis dan ijma' ulama' sebagai berikut: ${ }^{36}$

Al-Qur'an: “...Dan jika kamu ingin anakmu disusukan oleh orang lain, maka tidak ada dosa bagimu memberikan pembayaran dengan cara yang patut...".(QS. al-Baqarah 2: 233). ${ }^{37}$

Surat al-Baqarah ayat 233 di atas merupakan dasar yang dapat dijadikan landasan hukum dalam persoalan sewa menyewa. Karena dalam ayat tersebut diterangkan bahwa memakai jasa

\footnotetext{
${ }^{33}$ Ibid.

${ }^{34}$ Amir Syarifuddin, Garis-Garis Besar Fiqh (Jakarta: Kencana, 2003).216

${ }^{35}$ Ibid. 216

${ }^{36}$ Zuhaili, Fiqih Islam Wa Adillatuhu.2801

${ }^{37}$ RI, Al-Qur'an Kemenag.37
} 
juga merupakan bentuk sewa menyewa, oleh karena itu harus diberi upah atau pembayarannya sebagai ganti rugi dari sewa terhadap jasa tersebut. ${ }^{38}$

\section{Hadis:}

Dari Abu Hurairah Rasulullah SAW bersabda: "Dari Abu Hurairah sesungguhnya Rasulullah bersabda: "Berikanlah upah kepada orang yang bekerja sebelum keringatnya kering". (HR. Ibnu Majah). ${ }^{39}$

Dari Sa'id bin Musayyib: "Dari Sa'id bin Musayyib, dari Sa'id berkata: Dahulu kami menyewa tanah dengan bayar tanaman yang tumbuh, lalu Rasulullah SAW melarang atas hal itu, dan Rasul memerintahkan kami untuk membayarnya dengan emas atau perak". (HR. Ahmad, Abu Daud, dan Nasa'i).

Dari Ibnu Abbas: "Dari Ibnu Abbas RA berkata: Sesungguhnya Nabi SAW berbekam, lalu beliau memberikan upah kepada orang yang membekam". (HR. Ahmad, Bukhari dan Muslim).

\section{Ijma':}

Para Ulama' pada zaman sahabat telah sepakat atas dibolehkan akad ijarah sebelum adanya Abu bakar al-Ashim, Ibnu Aliyah dan lain-lain untuk memenuhi kebutuhan manusia dalam hal menggunakan manfaat. ${ }^{40}$ Rukun Ijarah menurut jumhur ulama' ada empat, yaitu: Aqidayn (dua belah pihak yang berakad), sighat (ijab dan qabul), ujrah (upah), manfaat. ${ }^{41}$ Disamping rukun di atas, ijarah juga harus memenuhi syaratsyarat sebagai berikut:

1. Syarat in'iqad (terjadinya akad): Adapun Aqidayn (kedua belah pihak yang berakad) harus berakal. Maka ijarah tidak sah jika dilakukan oleh orang gila dan anak kecil yang belum mumayyiz sebagaimana jual beli tidak sah jika

\footnotetext{
38 Yazid, Hukum Ekonomi Islam (Fiqh Muamalah).196

${ }^{39}$ Zuhaili, Fiqih Islam Wa Adillatuhu.3803

${ }^{40} \mathrm{Ibid}$.

${ }^{41}$ Wahbah Zuhaili, Al-Fiqh Al-Islamy Wa Adillatuh, n.d.3803
} 
dilakukan oleh orang gila dan anak kecil yang belum mumayyiz. Terdapat perbedaan pendapat di kalangan ulama' empat madzhab, yakni:

a. Menurut Ulama' Hanafiyah: tidak mensyaratkan adanya unsur baligh untuk in'iqad (terjadinya akad) dan nafadz (berlakunya akad). Dengan demikian anak kecil yang mumayyiz sah melakukan akad ijarah. Jika objek ijarah bukan milik sendiri, maka akad akan sah jika didampingi walinya.

b. Menurut Ulama' Malikiyah: Sesungguhnya tamyiz merupakan syarat ijarah dan jual beli. Sedangkan baligh merupakan syarat berlakunya akad. Maka anak kecil yang mumayyiz sah untuk melakukan ijarah, namun tergantung pada keridlaan walinya.

c. Menurut Ulama' Syafi'iyah dan Hanabilah: disyaratkan mukallah, yaitu baligh dan berakal untuk terjadinya akad ijarah. ${ }^{42}$

2. Syarat nafadz (berlakunya akad): Yang termasuk syarat berlakunya akad ijarah adalah adanya kepemilikan atau penguasaan yang melekat pada 'aqid. Dengan demikian ijarah al fudlul (tidak adanya kepemilikan atau penguasaan dari 'aqid) maka tidak bisa untuk melakukan akad ijarah.

3. Syarat sah ijarah:

a. Syarat yang berhubungan dengan 'aqid : Adanya keridlaan dari kedua belah pihak yang berakad sebagaimana dalam akad jual beli. Sebagaimana firman Allah SWT dalam surat an-Nisa' ayat 29 yang berbunyi: ${ }^{43}$ "Wahai orang-orang yang beriman, Janganlah kamu saling memakan harta sesamamu dengan jalan yang batil (tidak benar). Kecuali dalam perdagangan yang berlaku atas dasar suka sama suka di antara kamu...". (QS. an-Nisa' 4: 29). ${ }^{44}$

\footnotetext{
${ }^{42}$ Zuhaili, Fiqih Islam Wa Adillatuhu.3806

${ }^{43}$ Ibid.3807-3808

${ }^{44}$ RI, Al-Qur'an Kemenag.83
} 
b. Syarat yang berhubungan dengan ma'qud 'alaih: Objek ijarah harus bermanfaat dengan jelas. Artinya adanya kejelasan dari segi manfaat, jangka waktu, dan jenis pekerjaan (jika ijarah jasa atau pekerjaan seseorang). ${ }^{45}$

c. Syarat yang berhubungan dengan kondisi ma'qud 'alaih: Kondisi barang yang dijadikan objek ijarah adalah berupa sesuatu yang bisa diterima (tampak). Apabila sesuatu barang yang tidak dapat diterima atau dimiliki maka ijarah tidak sah, sebagaimana larangan Rasulullah dalam hal jual beli barang yang tidak bisa diterima (tidak tampak). Ijarah adalah cabang dari jual beli, maka segala larangan yang berlaku dalam jual beli maka berlaku juga dalam ijarah. ${ }^{46}$

d. Syarat yang berhubungan dengan ujrah (imbalan): Imbalan yang diberikan harus berupa sesuatu yang jelas diketahui. Syarat ini merupakan kesepakatan dari para Ulama' dan berlaku juga dalam jual beli. Keharusan dari kejelasan ujrah berdasarkan hadis Rasulullah SAW: "Barang siapa menyewa seseorang untuk bekerja, maka hendaklah ia beritahu upahnya”.(HR. Abd ar-Razzaq dan al-Baihaqi). Imbalan tidak boleh sejenis dengan ma'qud 'alaih (objek), misalnya sewa rumah dibayar dengan rumah, sewa kendaraan dibayar dengan kendaraan, sewa kebun dibayar dengan kebun dan lain-lain. ${ }^{47}$

\section{Asal Usul dan Mekanisme Praktik Jasa Penitipan Mobil di Rusunawa Tanah Merah Utara Surabaya}

Praktik jasa penitipan mobil di Rusunawa Tanah Merah Surabaya berjalan sejak berfungsinya Rusunawa Tanah Merah tahap dua, yaitu Januari 2013 dan berjalan hingga sekarang. Praktik jasa penitipan mobil di Rusunawa Tanah Merah Surabaya berawal dari salah satu warga internal rusun yang berprofesi sebagai sopir dari suatu perusahaan, kemudian

\footnotetext{
${ }^{45}$ Zuhaili, Fiqih Islam Wa Adillatuhu.3809

${ }^{46}$ Ibid. 3822

${ }^{47}$ Ibid. 3827
} 
mobil perusahaan tempat dia bekerja itu dibawa pulang dan diparkirkan di halaman Rusunawa Tanah Merah Surabaya. Seiring berjalannya waktu, kegiatan yang dilakukan oleh salah satu warga tersebut mengundang minat dari warga eksternal Rusun yang memiliki mobil untuk menitipkan mobilnya di halaman Rusunawa Tanah Merah Surabaya. ${ }^{48}$

Kemudian salah satu warga eksternal Rusun yang berminat untuk menitipkan mobilnya di halaman Rusun tersebut mengutarakan ketertarikannya tersebut dengan cara langsung menemui warga internal Rusun yang memarkirkan mobil di halaman Rusun. ${ }^{49}$ Tindakan selanjutnya yang dilakukan warga internal Rusun tersebut yaitu berdiskusi dengan pengelola dan seluruh warga internal Rusun lainnya mengenai hal minatnya warga eksternal Rusun. Maka hasil dari diskusi menjadi kesepakatan diantara warga rusun, pengelola rusun dan pemilik mobil dengan menetapkan tarif sebesar Rp. 300.000 per bulan.

Kemudian ujrah dari praktik jasa penitipan mobil di Rusunawa Tanah Merah Utara Surabaya di bagi hasil dengan presentase $60 \%$ masuk ke kas rusun dan $40 \%$ untuk beberapa warga rusun yang menjadi penanggung jawab jasa penitipan mobil. Namun kenyataan presentase hasil yang diambil oleh penanggung jawab jasa lebih besar daripada hasil yang masuk ke dalam kas Rusunawa. Disini terdapat kecurangan yang dilakukan oleh penanggung jawab jasa penitipan mobil.50 Selain itu sering terjadi kelalaian yang dilakukan oleh penanggung jawab jasa penitipan mobil yang tentu merugikan bagi pemilik mobil. ${ }^{51}$ Terhitung selama lima tahun berjalannya praktik jasa penitipan mobil di Rusunawa Tanah Merah Surabaya, yaitu mulai dari tahun 2013 sampai sekarang tahun 2018 terhitung telah ada sekitar 20 unit mobil milik warga

\footnotetext{
${ }^{48}$ Rohman, Wawancara, Warga Rusun (penyedia jasa penitipan mobil), 09 Juni 2018.

${ }^{49}$ Soleh, Wawancara, Warga eksternal Rusun (pemilik mobil), 08 Juni 2018.

${ }^{50}$ Ahmad Rifa'I, Wawancara,....

${ }^{51}$ Shodiq, Wawancara, Pemilik mobil, 08 Juli 2018.
} 
eksternal Rusun yang dititipkan di halaman Rusunawa Tanah Merah Surabaya. ${ }^{52}$

Dengan adanya kecurangan dan kelalaian yang dilakukan oleh penanggung jawab jasa penitipan mobil di Rusunawa Tanah Merah Utara Surabaya tentu merupakan perbuatan yang tidak diperbolehkan dan merugikan bagi beberapa pihak. Kecurangan terkait presentase pembagian hasil dari ujrah tersebut memang perbuatan yg tidak diperbolehkan karena tidak sesuai dengan kesepakatan awal akad. ${ }^{53}$ Kemudian kelalaian yang dilakukan oleh penanggung jawab jasa penitipan mobil jelas merugikan bagi pemilik mobil. 54

\section{Dampak Dari Praktik Jasa Penitipan Mobil di Rusunawa Tanah Merah Utara Surabaya.}

Adanya Rusunawa Tanah Merah Surabaya dan mempunyai halaman yang luas, tentu sangat menguntungkan bagi pihak internal Rusunawa Tanah Merah Utara Surabaya.Hal itu sangat bagus untuk kemajuan keuangan Rusunawa Tanah Merah Utara Surabaya dan menambah penghasilan bagi warga internal rusun. ${ }^{55}$ Selain itu juga sangat membantu bagi warga eksternal rusun yang memiliki mobil yang tidak memiliki garasi agar bisa menggunakan halaman rusun sebagai tempat untuk menitipkan mobilnya dengan biaya sebesar Rp. 300.000 yang harus dibayar oleh pemilik mobil setiap bulannya. ${ }^{56}$

Namun dalam praktik jasa penitipan mobil di Rusunawa Tanah Merah Utara Surabaya juga terdapat dampak negatif yang ditimbulkan akibat perbuatan yang tidak diperbolehkan, yaitu kecurangan dalam hal pembagian hasil dari ujrah yang

\footnotetext{
${ }^{52}$ Fauzi, Wawancara, Warga Rusun (penyedia jasa penitipan mobil), 09 Juni 2018.

${ }^{53}$ Ahmad Rifa'I, Wawancara,....

${ }^{54}$ Zaini, Wawancara, Warga Rusun (yang terganggu atau dirugikan), 07 Juni 2018.

${ }^{55}$.Fauzi, Wawancara, Warga Rusun.....

${ }^{56}$ Robi, Wawancara, Warga eksternal Rusun (pemilik mobil), 08 Juni 2018
} 
dihasilkan dari jasa penitipan mobil tersebut. Pada kesepakatan awal mengenai presentasepembagian hasil dari ujrah jasa penitipan mobil tersebut adalah $60 \%$ masuk ke kas rusun dan $40 \%$ dinikmati oleh penanggung jawab jasa penitioan mobil. Namun kenyataannya presentase pembagian hasil yang dinikmati oleh penanggung jawab jasa penitipan mobil tersebut lebih besar daripada hasil yang masuk ke kas rusun.Kecurangan tersebut adalah sesuatu yang tidak diperbolehkan.

Selain itu juga terdapat kelalaian yang dilakukan oleh penanggung jawab jasa penitipan mobil di Rusunawa Tanah Merah Utara Surabaya.Hal itu tentu sangat merugikan bagi warga eksternal rusun yang menitipkan mobil di Rusunawa Tanah Merah Utara Surabaya, karena ada beberapa mobil yang lecet namun penanggung jawab jasa penitipan mobil tidak mau tanggung jawab dengan adanya kerugian tersebut.

Dengan adanya hal itu bisa diketahui bahwa memang dalam praktik jasa penitipan mobil di Rusunawa Tanah Merah Utara Surabaya terdapat dampak positif yang ditimbulkan, namun, terdapat juga dampak negatif yang ditimbulkan dari praktik jasa penitipan mobil di Rusunawa Tanah Merah Utara Surabaya, yaitu:

1. Dampak Positif

a. Pemilik mobil merasa terbantu, karena adanya lahan untuk menitipkan mobilnya.

b. Memberikan rasa aman bagi pemilik mobil, karena ada yang mengawasi mobilnya. ${ }^{57}$

c. Mengembangkan pemasukan Rusunawa Tanah Merah Utara Surabaya. ${ }^{58}$

d. Menambah penghasilan bagi warga rusun yang menjadi penanggung jawab jasa penitipan mobil. ${ }^{59}$

2. Dampak Negatif

\footnotetext{
${ }^{57}$ Robi, Wawancara, Warga eksternal Rusun (Pemilik mobil),....,

${ }^{58}$ Ahmad Rifa'I, Wawancara, Pengelola Rusun......

${ }^{59}$ Rohman, Wawancara, Warga Rusun....
} 
Dengan adanya dampak positif yang ditimbulkan dari praktik jasa penitipan mobil di Rusunawa Tanah Merah Surabaya, bukan berarti tidak ada dampak negatif yang ditimbulkan. Ada juga dampak negatif yang ditimbulkan dari praktik jasa penitipan mobil di Rusunawa Tanah Merah Surabaya, diantaranya yaitu:

a. Dengan adanya kecurangan yang dilakukan oleh penanggung jawab jasa penitipan mobil, tentu pengelola dan warga rusun yang lain merasa sangat dicurangi. 60

b. Pemilik mobil merasa dirugikan dengan adanya kelalaian yang sering dilakukan oleh penanggung jawab jasa penitipan mobil. 61

c. Praktik jasa penitipan mobil tersebut menjadi jalan bagi penanggung jawab jasa penitipan mobil di Rusunawa Tanah Merah utara Surabaya untuk berbuat sesuatu yang dilarang yaitu curang dan lalai. ${ }^{62}$

d. Menyebabkan perselisihan bagi semua warga rusun disebabkan oleh kecurangan yang dilakukan penanggung jawab jasa penitipan mobil di Rusunawa Tanah Merah Utara Surabaya. ${ }^{63}$

Berikut adalah beberapa kutipan dari wawancara langsung yang penulis lakukan dengan warga internal Rusunawa Tanah Merah Surabaya yang merasa dirugikan dengan adanya praktik jasa penitipan mobil di Rusunawa Tanah Merah Surabaya:

"Di kesepakatan awal kami telah sepakat bahwa presentase pembagian hasil ujrah dari praktik jasa penitipan mobil di Rusunawa Tanah Merah Utara Surabaya adalah 60\% masuk ke kas Rusun dan 40\%

\footnotetext{
${ }^{60}$ Ghoni, Wawancara, Warga Rusun (yang terganggu atau dirugikan), 07 Juni 2018.

${ }^{61}$ Soleh, Wawancara, Warga eksternal Rusun (pemilik mobil),....,

${ }^{62}$ Luthfi, Wawancara, Warga Rusun (yang terganggu atau dirugikan), 07 Juni 2018.

${ }^{63}$ Riyati, Wawancara, Warga Rusun (yang terganggu atau dirugikan), 07 Juni 2018 .
} 
dinikmati oleh penanggung jawab jasa penitipan mobil. Namun kenyataannya hasil yang dinikmati oleh penanggung jawab jasa penitipan mobil lebih besar daripada yang masuk ke kas rusun.Mereka telah mencurangi kami semua." 64

"Kami merasa kecewa dan dicurangi oleh penanggung jawab jasa penitipan mobil, karena presentase pembagian hasil dari ujrah jasa penitipan mobil tersebut tidak sesuai dengan ksepakatan awal." 65

"Setelah saya mengetahui adanya praktik jasa penitipan mobil di Rusunawa Tanah Merah Surabaya ini sebenarnya kami merasa senang, namun yang menjadi masalah bagi kami adalah adanya kecurangan dalam pembagian hasil ujrah dari praktik jasa penitipan mobil tersebut. Tentu hal itu membuat semua warga rusun gusar dengan perbuatan curang tersebut" 66

"Saya adalah salah satu pihak yang dirugikan akibat dari kelalaian penanggung jawab jasa penitipan mobil di Rusunawa Tanah Merah Utara Surabaya.Akibatnya saya mengalami masalah di mobil saya, yaitu mobil saya banyak yg lecet."67

Dengan fenomena praktik jasa penitipan mobil di Rusunawa Tanah Merah Utara Surabaya tersebut memang terdapat kecurangan dan kelalaian yang dilakukan oleh penanggung jawab jasa penitipan mobil yang selanjutnya menjadi masalah bagi pengelola, warga rusun yang lain dan para pemilik mobil. Hal tersebut tentu sangat merugikan bagi pihak-pihak yang terkait. Bagi pengelola rusun dan warga rusun yang lain mereka merasa dicurangi dan dibohongi oleh penanggung jawab jasa penitipan mobil karena pembagian hasil yang mereka terima tidak sesuai dengan kesepakatan awal. Bagi pemilik mobil mereka merasa dirugikan dengan

\footnotetext{
${ }^{64}$ Ibid.

${ }^{65}$ Luthfi, Wawancara, Warga Rusun,.....,

${ }^{66}$ Riyati, Wawancara, Warga Rusun,.....,

${ }^{67}$ Soleh, Wawancara, Warga eksternal Rusun (pemilik mobil),....,
} 
kelalaian yang dilakukan oleh penanggung jawab jasa penitipan mobil, akibatnya ada beberapa mobil yang dititipkan di halaman rusun mengalami kerusakan dan lecet akibat dari kelalaian penanggung jawab jasa penitipan mobil tersebut. Dengan berbagai masalah yang terjadi dalam praktik jasa penitipan mobil di Rusunawa Tanah Merah Utara Surabaya tersebut jelas menimbulkan kemafsadatan bagi para pihak yang merasa dirugikan.

\section{Analisis Sadd al-Dhari'ah Terhadap Praktik Jasa Penitipan Mobil di Rusunawa Tanah Merah Utara Surabaya}

Dalam Islam terdapat salah satu metode istinbath hukum yang diakui keberadaannya dan digunakan oleh para Ulama' untuk suatu hukum yang belum ada nashnya, yaitu Sadd al-Dhari'ah. ${ }^{68}$ Penetapan hukum secara Sadd al-Dhari'ah bertujuan untuk memudahkan tercapainya kemashlahatan dan jauhnya kemungkinan terjadinya kerusakan (kemafsadatan). Untuk mencapai hal itu syari'at menetapkan perintah-perintah dan larangan dalam memenuhi perintah dan menghentikan larangan. ${ }^{69}$ Ditinjau dari analisis di atas bahwa praktik jasa penitipan mobil di Rusunawa Tanah Merah Utara Surabaya menimbulkan dampak positif dan dampak negatif.

Kegiatan mu'amalah yang dilakukan di kalangan masyarakat yang berhubungan dengan urusan duniawi selalu berubah dan berkembang sesuai dengan situasi dan kondisi yang ada. Apabila masyarakat pelaku mu'amalah tidak memperhatikan kemashlahatan, maka mereka akan mengalami kesulitan dalam menjalani kehidupan sehari-harinya. Oleh karena itu mereka para pelaku mu'amalah hendaknya mengambil jalan yang baik dan menghindari jalan yang buruk, dengan cara berpegang teguh pada prinsip yang telah diatur dalam syari'at Islam. Sehingga hal tersebut mendorong penulis untuk melakukan analisis terhadap praktik jasa penitipan

\footnotetext{
${ }^{68}$ Sulaiman Abdullah, Sumber Hukum Islam Permasalahan Dan Fleksibilitasnya (Jakarta: Sinar Grafika, 2004).164

${ }^{69}$ Kamal Muchtar, Ushul Fiqh Jilid 1 (Yogyakarta: PT. Dana Bakhti, 1995).156
} 
mobil di Rusunawa Tanah Merah Utara Surabaya berdasarkan metode Sadd al-Dhari'ah.

Pada bagian ini kami akan menjelaskan tentang analisis Sadd al-Dhari'ah terhadap praktik jasa penitipan mobil di Rusunawa Tanah Merah Utara Surabaya. Dalam praktik jasa penitipan mobil di Rusunawa Tanah Merah Utara Surabaya memang ada dampak positif (mashlahah) dan keuntungan bagi semua pihak yang terlibat, yaitu bagi pengelola rusun, semua warga rusun, penanggung jawab jasa penitipan mobil, dan pemilik mobil. Akantetapi tedapat dampak negatif (kemafsadatan) dan kerugian yang mengiringi praktik jasa penitipan mobil di Rusunawa Tanah Merah Utara Surabaya akibat dari kecurangan dan kelalaian yang dilakukan oleh penanggung jawab jasa penitipan mobil di Rusunawa Tanah Merah Utara Surabaya.

Praktik jasa penitipan mobil di Rusunawa Tanah Merah Utara Surabaya memang menguntungkan bagi para pihak yang terkait. Namun kemudian kegiatan tersebut membuka jalan bagi salah satu pihak untuk melakukan perbuatan yang dilarang dalam Islam, yaitu mencurangi dan merugikan bagi para pihak yang berakad, seperti yang dilakukan oleh penanggung jawab jasa penitipan mobil di Rusunawa Tanah Merah Utara Surabaya yang tentu sangat merugikan berbagai pihak.

Maka dari itu analisis Sadd al-Dhari'ah pada permasalahan di atas harus dicegah dan ditutup guna menghindari terganggunya pengelola dan warga internal Rusunawa Tanah Merah Surabaya yang tidak setuju atas adanya praktik jasa penitipan mobil di Rusunawa Tanah Merah Surabaya. Dengan demikian, kegiatan mu'amalah berupa akad ijarah yang sesuai dengan prinsip dasar mu'amalah yang sangat penting dalam menetapkan hukum Islam demi menciptakan kemashlahatan dan menghindari kemafsadatan atau kerusakan.

Dalam kaidah fikih dijelaskan, bahwa jika terjadi pertentangan antara kemafsadatan dan kemashlahatan pada 
suatu perbuatan atau jika satu perbuatan ditinjau dari segi terlarang, karena mengandung kerusakan dan ditinjau dari segi yang lain mengandung kemaslahatan, maka segi larangan yang harus didahulukan. Maka dari itu peran sesama muslim wajib untuk mencegah kemungkaran atau kerusakan semampunya. Karena jika kemungkaran tidak dicegah atau didiamkan saja, maka akan semakin merajalela. Dengan demikian kemungkaran harus dicegah dan ditegaskan agar tidak berkelanjutan dan tidak menimbulkan semakin banyak pihak yang dirugikan akibat dari adanya kemungkaran.

Dalam praktiknya di masyarakat, terdapat berbagai macam bentuk Sadd al-Dhari'ah, dilihat dari tingkat kerusakan yang ditimbulkannya. Menurut Imam al-Syatibi ada empat macam tingkat kerusakan yang ditimbulkan, yaitu: ${ }^{70}$

1. Suatu perbuatan yang dilakukan membawa kemafsadatan secara pasti. Artinya, bila al-Dhari'ah itu tidak dihindari maka akan menimbulkan kerusakan. Misalnya, menggali lubang di depan rumah seseorang, karena apabila seseorang pemilik rumah tersebut keluar dari rumahnya maka otomatis orang itu akan masuk ke lubang tersebut.

2. Suatu perbuatan yang boleh dilakukan karena jarang membawa kepada kemafsadatan. Misalanya, menggali sumur di kebun milik sendiri yang jarang dilalui orang lain. Namun tidak menutup kemungkinan apabila ada orang yang melintasi kebun itu akan masuk ke dalam lubang sumur.

3. Suatu perbuatan yang biasanya atau besar kemungkinan membawa kepada kemafasadatan. Misalnya, menjual senjata kepada penjahat yang kemungkinan besar akan digunakan untuk membunuh atau menyakiti orang lain.

4. Suatu perbuatan yang boleh dilakukan karena mengandung kemashlahatan, namun juga membawa kepada kemafsadatan. Misalnya, praktik jasa penitipan mobil di Rusunawa Tanah Merah Surabaya. Dalam praktiknya jasa penitipan mobil tersebut boleh dilakukan karena telah

${ }^{70}$ Haroen, Ushul Fiqh 1.170 
memenuhi syarat ijarah yang telah ditetapkan dalam Islam. Namun apabila penulis menganalisis lebih dalam lagi, praktik tersebut menimbulkan masalah baru bagi banyak pihak. Banyak pihak yang merasa terganggu dan dirugikan, karena adanya kecuarangan dan kelalaian yang dilakukan oleh penanggung jawab jasa penitipan mobil di Rusunawa Tanah Merah Utara Surabaya. Penanggung jawab jasa penitipan mobil melakukan kecuarangan, karena tidak sesuai dengan kesepakatan yang telah disepakati dengan pengelola rusun dan warga rusun yang lain terkait pembagian hasil dari ujrah penitipan mobil. Kemudian kelalaian yang dilakukan oleh penanggung jawab jasa penitipan mobil yang menyebabkan kerusakan beberapa mobil yang tentu sangat merugikan beberapa pemilik mobil.

Dengan demikian, praktik yang terjadi sesuai dengan Sadd al-Dhari'ah golongan keempat. Karena adanya praktik ijarah dalam praktik jasa penitipan mobil di Rusunawa Tanah Merah Surabaya tersebut hukum asalnya boleh dilakukan, namun jika dilihat dari sisi yang lain praktik ijarah ini juga mengandung kemafsadatan.

Dari hasil penelitian ini perlu diterapkan penetapan hukum Sadd al-Dhari'ah terhadap praktik jasa penitipan mobil di Rusunawa Tanah Merah Surabaya. Sebab jika dilihat dari pelaksanaan praktik ijarah yang terjadi lebih besar kemafsadatan yang ditimbulkan daripada kemashlahatannya. Karena jalan atau perbuatan yang menimbulkan kemafsadatan atau kerusakan yang lebih besar itu hukumnya haram, maka harus dicegah dan ditutup, sebagaimana kaidah Sadd alDhari'ah yang berlaku, yaitu "Menolak keburukan (mafsadah) lebih diutamakan daripada meraih kebaikan (mashlahah). ${ }^{71}$

\section{Penutup}

Berdasarkan uraian yang telah dijelaskan dan dianalisis di atas, maka penulis dapat mengambil beberapa kesimpulan

${ }^{71}$ Djazuli, Kaidah-Kaidah Fiqh.164 
yang menjadi jawaban beberapa permasalahan yang telah dirumuskan. Kesimpulan tersebut adalah mengenai mekanisme praktik jasa penitipan mobil di Rusunawa Tanah Merah Surabaya adalah praktik ijarah yang sah, karena telah memenuhi syarat dan rukun ijarah yang telah ditetapkan dalam Islam. Mengenai dampak yang mengiringi praktik jasa penitipan mobil di Rusunawa Tanah Merah Surabaya jika dianalasis menurut metode penetapan hukum Sadd al-Dhari'ah dapat disimpulkan bahwa praktik tersebut harus dicegah, karena merugikan berbagai pihak yang terkait.

\section{Daftar Pustaka}

Abdullah, Boedi, and Ahmad Saebani. Metode Penelitian Ekonomi Islam. Bandung: Pustaka Setia, 2014.

Abdullah, Sulaiman. Sumber Hukum Islam Permasalahan Dan Fleksibilitasnya. Jakarta: Sinar Grafika, 2004.

Al-Jauzaiyah, Ibn al-Qayyim. A'lam Al-Muwaqi'in, Jilid 3. Beirut:

Dar al-Kutub al-'Ilmiyah, 1996.

Al-Syatibi, Ibrahim bin Musa al-Lakhmi al-Gharnathi al-Maliki. , Al-Muwafaqat Fi Ushul Al-Fiqh Juz 3. Beirut: Dar alMa'rifah, n.d.

Al-Unzi, Abdullah bin Yusuf bin 'Isa bin Ya'qub al-Ya'qub alJadi.' Taysir 'Ilmi Ushul Al-Fiqh. Beirut: Muassasah alRayyan li al-Thaba'ah, 1997.

Ash-Shiddieqy, Hasbi. Falsafah Hukum Islam. Jakarta: PT. Bulan Bintang, 1993.

Asmawi. Perbandingan Ushul Fiqh. Jakarta: Sinar Grafika Offest, 2011.

Djazuli, Ahmad. Kaidah-Kaidah Fiqh. Jakarta: Kencana, 2006.

Haroen, Nasrun. Ushul Fiqh 1. Jakarta: Logos, 1996.

Harun, Nasrun. Fiqh Muamalah. Jakarta: Gaya Media Pratama, 2000.

Jazil, Saiful. Fiqih Mu'amalah. Surabaya: UIN Sunan Ampel Press, 2014.

Muchtar, Kamal. Ushul Fiqh Jilid 1. Yogyakarta: PT. Dana Bakhti, 1995.

Nawawi, Ismail. Ekonomi Islam- Teori, Sistem, Dan Aspek 
Hukum. Surabaya: CV. Putra Media Nusantara, 2009.

Nurfaizal. "Prinsip-Prinsip Muamalah Dan Implementasinya Dalam Hukum Perbankan Indonesia." Jurnal Hukum Islam Vol.13 (2013): 193.

RI, Kemenag. Al-Qur'an Kemenag. Jakarta: Lajnah Pentashihan Mushaf Al-Qur'an, 2018.

Shidiq, Sapiudin. Ushul Fiqh. Cet.1. Jakarta: Prenada Media Group, 2011.

Syarifuddin, Amir. Garis-Garis Besar Fiqh. Jakarta: Kencana, 2003.

Yahya, Mukhtar, and Fatchurrahman. Dasar-Dasar Pembinaan Hukum Islam. Bandung: PT. Al-Ma'arif, 1986.

Yazid, Muhammad. Hukum Ekonomi Islam (Fiqh Muamalah). Sidoarjo: CV Cahaya Intan XII, 2014.

- - - Hukum Ekonomi Islam (Fiqih Muamalah). Surabaya: UIN Sunan Ampel Press, 2014.

Zuhaili, Wahbah. Al-Fiqh Al-Islamy Wa Adillatuh, n.d.

-_- Fiqih Islam Wa Adillatuhu, 2011.

"Pengertian Fiqih Muamalah." Accessed March 30, 2018. http://artikelilmiahlengkap.blogspot.com/.

Rohman. Wawancara. Warga Rusun (penyedia jasa penitipan mobil). 09 Juni 2018.

Shodiq. Wawancara. Pemilik mobil. 08 Juli 2018.

Soleh. Wawancara. Warga eksternal Rusun (pemilik mobil). 08 Juni 2018.

Zaini. Wawancara. Warga Rusun (yang terganggu atau dirugikan). 07 Juni 2018. 